\title{
Combined Development of Speed and Strength Qualities of the Weightlifters
}

\author{
Viktor Ivanovich Zhukov
}

\author{
Anatolii Mikhailovich Doronin
}

Alii Ruslanovich Mamii

Federal State Budget Institution of Higher Professional Education «Adyghe State University» (ASU)

385000, Maikop, street Pervomayskaya, 208, Russian Federation; Email: nisadgu@yandex.ru

Doi:10.5901/mjss.2015.v6n5s2p151

\begin{abstract}
In the issue of sports skills improvement, application of various training machines appears to be promising, since they ensure interrelated upgrade of various motor skills increasing the efficiency of exercise lessons without a significant increase in average loads. Opportunities for optimal adjustment of the exercising conditions appeared to the maximum extent with application of a training machine with variable resistance modes. A comparative analysis of the dynamic and kinematic characteristics of barbell presses on the machine discovered that all parameters characterizing the strength display degree and structure, its duration, barbell motion speeds in the various trajectory points, are subject to changes. The obtained experimental data show that the results in snatches, clean and jerks, and the combined total increased statistically significantly. An average increment of the back strength in the control group amounted to $15.0 \mathrm{~kg}$; and in the experimental group, where the control action machine was applied, it was equal to $26.7 \mathrm{~kg}$. The barbell speed change values during the power clean in the experimental and control groups show that the average gain in the maximum speed in the experimental group amounted to $0.15 \mathrm{~m} / \mathrm{sec}$, and in the control group $-0.04 \mathrm{~m} / \mathrm{sec}$. A comparison of the obtained data allows drawing the conclusion, that application of the control action machine in the training process produces a significant impact on the strength and speed parameters. Performance of the jerk exercises on a machine with variable resistance modes and primarily with the application of modes when the load is decreased as the barbell motion speed is increased, fully meets the requirements of the combined development method and observes the "dynamic conformance" principle.
\end{abstract}

Keywords: Training process optimization, training machine, variable resistance modes, weight-lifting exercises, biomechanical parameters.

\section{Introduction}

The sports training process is comprised of the organically interrelated components: physical, sport and technical, tactic and psychological exercises. Physical conditioning provides favorable pre-requisites for solution of the sport and technical, tactic and psychological training tasks.

Many works are devoted to identification of regularities of the physical skills training (rate of speed, muscular strength, endurance, etc.) (Diachkov, 1972; Ratov, 1972; Slobodian, 1973; Ivanov, 1976; Bozhko and Baroga, 1979; Drozdov, 1982; Verkhoshanskii, 1988; Zhukov, 2006; Zatsiorsky, 2006; Baechle, 2008, etc.).

Physical qualities of an athlete can be developed with the help of exercises-they impose different requirements to certain qualities' development. Each physical exercise solves many sports training tasks in a varying degree.

The most attractive ones from them are those, which are aimed at the development of the physical qualities complying with the selected sport event's specific nature, and are oriented at the limiting (maximum possible) degree of such qualities development.

The objective of the special physical training is to intensify the muscles' work in the motor conditions specific for each particular kind of sport (Vaitsekhovskii, 1979; Verkhoshanskii, 1988; Samsonova, 2011, etc.).

One of the main conditions of high results achievement in the speed and strength kinds of sports is the speed and strength fitness of athletes (Diachkov, 1972; Korenberg, 1979; Medvedev, 1981; Drozdov, 1982; Verkhoshanskii, 1988; Cherkesov, 1993, etc.).

It is known that the level of speed and strength qualities development is to a certain extent determined by the development of the strength qualities as such, and along with that-by the maximum values of motions speed (Vaitsekhovskii, 1979; Vorob'ev, 1981; Krasov, 1982; Stone, 2007; et al.). 
Sports results improvement depends on many factors, and primarily on the increase of the training load volume and intensity (Gisin, Lelikov, and Stepanova, 1982).

The tendency towards the further increase of the training work scopes persists in our time, too. However, an excessive increase in the work volume collides with other load components and negatively affects the efficiency of the process of physical and technical training of athletes (Ratov, 1972).

Due to the above-stated, we believe that sports skills improvement requires extension of training means and methods increasing efficiency of the exercises without significant increment of the training scope and intensity and allowing to disclose better the functional reserves of an athlete's body (Avanesov, 1970; Vorob'ev, 1981).

Special exercises must be similar with the kinematic and dynamic structure of the competitive exercises (Dobrovolskii, Chicherin, and Shchupletsov, 1977). Some authors also examined the dynamic and kinematic characteristics of the weightlifting competitive and special auxiliary exercises (Donskoi, 1972; Diachkov, 1972; Slobodian, 1973; Vorob'ev, 1981; Levshunov, 1982; et al.).

Based on the above-stated, we consider that the choice of special exercises should be made with account of all principles, excluding the check for the possible transfer and reinforcement of the motion technique's negative elements. It is important to pay special attention to the technique of special exercises, since athletes quickly adapt to them, thus limiting the development of necessary physical qualities and the achievement of a new development level. It is necessary to find non-traditional impacts on the athlete's body or such a combination of the known impacts, to which the body has not adapted yet.

In this regard, experts adhere to the approach of extended application of non-conventional training means in order to improve the sports skills: the use of devices, equipment, and techniques allowing to disclose the functional reserves of the athlete's body more fully (Cherkesov, 1993; Skripko, 2003; Zhukov, 2006; Mamii, 2006; et al.).

It is also prospective to apply various training machines providing interrelated improvement of various motor qualities and increasing efficiency of the exercises without a significant increase in the average value of the loads (Ratov, 1972; Cherkesov, Zhukov, and Doronin, 1991).

The objective of this work is the examination of the impact of the machine with the variable resistance modes on the combined development of the strength and speed qualities of the weightlifters in the training process.

\section{Methods and Materials}

For the solution of the set tasks, the following pedagogical and biomechanical research methods were used: the research and methodical literature analysis; pedagogical observations; pedagogical experiments; mathematical methods of the experiment data processing, the integrated technique of registering and processing biomechanical parameters:

- the vertical component of the support reaction force;

- the muscles pulling strength applied to the sports apparatus;

- the linear movement of the sports apparatus;

- the parameters of the travel speed of the biomechanical systems objects;

- $\quad$ the duration of the motion and of its constituent components.

For identification of the possibilities of impact of the machine with the variable resistance modes, a research was conducted to identify the peculiarities of barbell clean and jerk under various control actions on the weightlifter's motor apparatus.

In this respect, the biomechanical parameters of the classic clean and jerk performed in the natural conditions (without using the machine-the permanent resistance mode) and influenced by control actions (using the machine-the decreasing and increasing resistance mode) were compared. The research was conducted with involvement of the weightlifters who had various sports qualification-Master of Sports, Candidate in Master of Sports, I Rank.

Prior to the experiment, the biomechanical parameters of the classic clean and jerk among all the tested athletes were recorded, which characterized the technique of exercise performance-the support reaction force, the barbell displacement and speed, and the knee joint goniogram. The recording was done at the weights equal to $70 \%, 80 \%$, and $90 \%$ of the best result in this exercise.

During the research of the machine's control action on the weightlifter's motor apparatus, the load was selected so that the average resistance generated by it was equal to the barbell weight during the exercise performance in natural conditions, i.e. $70 \%, 80 \%$ and $90 \%$ of the best result.

We provide the results of the recording of biomechanical parameters of the performed exercises of Master of Sports Krasov (Krasov, 1982), which are typical for the whole group of athletes participating in the research. 


\section{Results}

\subsection{Changes in the competition-based exercises}

The obtained experimental data (Table A1) show that the results in snatches, clean and jerks, and the combined total increased in both groups. Such an increase has a statistically significant difference from the indicators of the athletes prior to the experiment. It should be noted that the comparative analysis of the results increment in the groups proves the existence of difference between them.

Table A1. Results of the comparative experiment in weightlifting

\begin{tabular}{|l|c|c|c|c|c|c|}
\hline \multirow{2}{*}{ Exercise } & \multicolumn{4}{|c|}{ Increment $(\mathrm{kg})$} & \multirow{2}{*}{} & \multirow{2}{*}{ Differences' significance } \\
\cline { 2 - 5 } & \multicolumn{2}{|c|}{ Control } & \multicolumn{2}{|c|}{ Experimental } & \multirow{2}{*}{ Difference } & \\
\cline { 2 - 5 } & $A$ & $\pm m$ & $A$ & $\pm m$ & & $<$ \\
\hline \hline Snatch & 4.8 & 0.039 & 11.5 & 0.090 & 6.7 & $<$ \\
\hline Jerk & 12.0 & 0.085 & 19.3 & 0.081 & 7.3 & $<$ \\
\hline Combined total & 16.8 & 0.081 & 30.8 & 0.15 & 14.0 & $>$ \\
\hline F (start) & 15.0 & 0.10 & 26.7 & 0.14 & 11.7 & $<$ \\
\hline F (second pull) & 22.5 & 0.13 & 23.5 & 0.17 & 1.0 & $<.0$ \\
\hline Squat & 12.0 & 0.09 & 22.3 & 0.11 & 10.3 & $<$ \\
\hline
\end{tabular}

Thus, in the control group, the increment of the barbell snatch results was equal to $4.8 \mathrm{~kg}$, of the clean and jerk-12.0 kg, and the combined total-16.8 kg, and in the experimental group-11.5 kg, $19.3 \mathrm{~kg}$, and $30.8 \mathrm{~kg}$, accordingly. Therefore, in the experimental group, the increment of results in the snatch was by $6.7 \mathrm{~kg}$ more than in the control one. The difference was significant.

The difference of the increase in clean and jerk results amounts to $7.3 \mathrm{~kg}$ and was also statistically significant.

The combined total was by $14.0 \mathrm{~kg}$ more that in the control group, and the difference was statistically significant.

The combined total value increase in the experimental group was by $14.0 \mathrm{~kg}$ more than in the control group, the difference is statistically significant.

Summarizing the above-specified results of the comparative analysis, we can conclude that application of a machine with variable resistance modes for jerk exercises has an advantage in contrast to the conventional exercise means.

For the purpose of determination of the dynamics of the main muscle groups' strength development, the indicators were registered, which characterize the maximum strength of the extensor muscles of the legs and the body. The following athletic exercises were used as the tests: squatting (hip extensors) and dead-lift (for body extensors) in the start and second pull positions.

\subsection{Change in the strength values}

The average increment of the back strength in the control group was equal to $15.0 \mathrm{~kg}$; and in the experimental group, where the control action machine was applied-26.7 kg.

Comparing the pulling force in the start position, we can note that the increment of the results in the experimental group was more by $11.7 \mathrm{~kg}$ than in the control group, and is statistically significant.

The force increment in the second pull position in the experimental group was $23.5 \mathrm{~kg}$, which was only by $1.0 \mathrm{~kg}$ larger than in the control group, where the average group indicator was equal to $22.5 \mathrm{~kg}$. No statistically significant difference was detected.

The control barbell squats demonstrated that the results increment achieved by the experimental group's athletes was equal to $22.3 \mathrm{~kg}$ on the average, while the control group had the result of $12.0 \mathrm{~kg}$. The difference of $10.3 \mathrm{~kg}$ was statistically significant.

\subsection{Value of the support reaction force change}

The presented results of the examination of the support reaction force impulse at upon barbell cleans by the weightlifters from the control and experimental groups proved that the total impulse of the support reaction force increased in both 
groups, but to a different extent (Table A2).

Table A2. Change of the force impulse at the clean within the period of the pedagogical experiment

\begin{tabular}{|c|c|c|c|c|c|c|}
\hline \multirow{3}{*}{ Periods and phases } & \multicolumn{4}{|c|}{ Increment } & \multirow{3}{*}{ Difference } & \multirow{3}{*}{ Differences' significance } \\
\hline & \multicolumn{2}{|c|}{ Control } & \multicolumn{2}{|c|}{ Experimental } & & \\
\hline & $A$ & $\pm m$ & $A$ & $\pm m$ & & \\
\hline I per. (\%) & 1.7 & 0.09 & 6.7 & 0.068 & 5.0 & $<<$ \\
\hline \begin{tabular}{|ll} 
II per. $(\%)$ \\
\end{tabular} & -1.7 & 0.09 & -6.7 & 0.068 & 5.0 & $<$ \\
\hline Job. (ns) & 74.0 & 0.84 & 177.0 & 1.3 & 103 & $<$ \\
\hline $2^{\text {nd }} \mathrm{ph} .(\%)$ & 5.4 & 0.038 & 8.2 & 0.087 & 2.8 & $>$ \\
\hline $\begin{array}{l}3^{\text {rd }} \mathrm{ph} .(\%) \\
\end{array}$ & -5.4 & 0.038 & -8.2 & 0.087 & 2.8 & $>$ \\
\hline Job. (ns) & 61.0 & 0.59 & 178.0 & 0.70 & 117.0 & $<$ \\
\hline
\end{tabular}

Thus, in the experimental group, the total force impulse increased by $177 \mathrm{~ns}$, while in the control group -by 74 ns. The change also influenced the ratio of the force impulse of the Ist $^{\text {st }}$ period in the experimental group, which increased by $6.7 \%$. Accordingly, the force impulse in the IId $^{\text {nd }}$ period also changed-in the experimental group by $6.7 \%$ and in the control group by $1.7 \%$.

A comparative analysis of the change of the support reaction force impulse at barbell clean in the control and experimental groups proved a significant difference in the results increment between these groups.

The large increment value of the total force impulse in the experimental group (103.0 ns) in contrast to the control group (the difference is significant) demonstrated the advantage of the training method with the application of the machine with variable resistance modes for achieving a larger force impulse in the process of exercising.

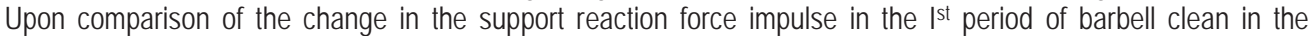
experimental and control groups, we need to note that its increase in the experimental group was by $5.0 \%$ larger than in the control group.

Accordingly, the support reaction force in the IInd period of barbell clean lifting in the experimental group decreased by $5.0 \%$ in contrast to the control group. The existing significant difference evidences that the method of training using the machine with variable resistance modes contributes to the more efficient fulfillment of the weightlifter's strength capabilities.

\subsection{Parameters of the barbell movement time and speed}

The barbell clean timing parameters were subject to some changes. For example, the total duration of the $\left.\right|^{\text {st }}$ and $I^{\text {nd }}$ periods' performance decreased in the experimental group by $0.15 \mathrm{sec}$ and in the control group by $0.04 \mathrm{sec}$. The difference of $0.11 \mathrm{~s}$ is statistically significant.

A study of the timing parameters of the examined periods in the percentage of the total time of their performance discovered an increase in the Ist $^{\text {st }}$ period duration in the experimental group equal to $1.7 \%$; and in the control group equal to $1.87 \%$. The duration of the IInd period in the groups decreased accordingly by $1.7 \%$ and $1.8 \%$.

The performed comparative analysis of the change in the $\left.\right|^{\text {st }}$ and IInd periods' duration in the experimental and control groups indicated the absence of any significant difference of the time parameters of these periods, since the difference equal to $0.83 \%$ was not statistically significant.

The indicators of the barbell clean speed change in the experimental and control groups show that the average increment of the maximum speed in the experimental group was equal to $0.15 \mathrm{~m} / \mathrm{sec}$, and in the control group- 0.04 $\mathrm{m} / \mathrm{sec}$.

A comparison of the obtained data allows drawing the conclusion that the application of the control action machine in the training process produces a significant impact on the speed parameters. Thus, at barbell clean, the difference in the take-off in the experimental and control groups amounted to $0.11 \mathrm{~m} / \mathrm{sec}$ (the difference is significant).

To check the validity of the performance of weightlifters participating in the comparative experiment, we calculated the rank correlation coefficient. Prior to the experiment, the coefficient value among the control group athletes was equal to 0.377 and in the experimental group- 0.361 . A comparative analysis of these indicators upon the experiment completion demonstrated that they had changed and amounted to 0.455 and 0.574 respectively, which is indicative of the optimization of the training impacts of the exercises performed in the arranged conditions. 


\section{Discussion}

The objective of our research was to determine the opportunities of optimal adjustment of the conditions of exercises performance in case of using a machine with variable resistance modes (through the example of weightlifting).

A comparative analysis of the indicators of dynamic and kinematic characteristics of barbell lifting on the machine with the variable resistance modes detected that the parameters characterizing the force display degree and structure, its duration, the barbell motion speeds in various trajectory points, were subject to changes.

A control action produces a significant impact on the force impulse value and the duration of the Ist $^{\text {and }}$ IInd $^{\text {periods. }}$ With the decreasing resistance mode, the range and duration of the Ist period increased significantly (in contrast to the barbell lifting in the permanent mode conditions) and the value of the $\|^{\text {nd }}$ period almost did not change.

The increasing mode not only increased the $\mathrm{II}^{\text {nd }}$ period duration, but also shortened the $\mathrm{I}^{\text {st }}$ period by a significant value. The total time of both periods significantly increased only at the decreasing resistance due to the longer duration of the $I^{\text {st }}$ period.

The driving impulse of the force of barbell clean slightly increased with the increase in the lifted weight. Its change occurred under the influence of various control actions. The maximum value of this parameter was registered in the conditions of the decreasing resistance mode. The minimum value-under the increasing one. It should be noted that in the IIn period of motion, the driving force impulse had almost the same value in all three cases.

In the result, the ratio by the periods depended on the value of the driving force impulse in the first part of the exercise. The prevailing influence of the decreasing resistance was expressed in the force impulse increase in the Ist $^{\text {st }}$ period, and of the increasing one-in occurrence of the greater force impulse in the IId $^{\text {nd }}$ period.

In our opinion, the obtained results can be explained as follows. In the decreasing mode, the athlete has comparatively more opportunities for fulfillment of his strength capabilities by means of the significant resistance created at the initial phases (barbell + decreasing load). Besides, the relatively slow speed of motion in this part of the exercise allows generating considerable force. The resistance decreasing during the motion contributes to the increase in the barbell movement speed and drop of the forces applied to the bar. This explains the decrease in the values of the full and driving force impulses in the IInd period.

Such efforts distribution complies with the law of natural muscles contraction, i.e. the contraction of a muscle lifting a weight is to be accompanied with the reduction in its stress (Fick, 1864; Sechenov, 1905) and is consistent with the provision that upon generation of small force, the largest muscle groups are mobilized and as the speed increases, the weaker, but quicker muscles are engaged (Verkhoshanskii, 1972; Ratov, 1974; Zhekov, 1976; Doronin, 2006), The performance of weightlifting clean and jerk exercises on a machine with variable resistance modes, and, primarily, with the use of the variable modes providing load reduction with the barbell motion speed increase, fully complies with the requirements of the combined development method (Diachkov, 1972) and adherence to the "dynamic conformance" principle (Verkhoshanskii, 1972).

A proof of the increased speed capabilities is the greater final speed of motion at the barbell clean. Upon comparison of peculiarities of the biomechanical characteristics of the barbell clean, the experimental group

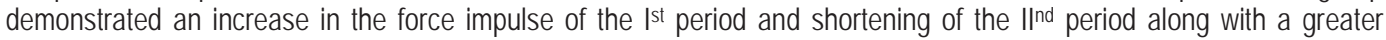
increase in the total force impulse. In our view, the obtained results can be explained by the cumulative effect of the exercises performed in the conditions of the decreasing resistance mode, as well as by the increased level of the intermuscular coordination (Ratov, 1972, Errera, 1981).

An increase of the strength values influenced the duration of the motion performance. Reduction of the total time of two periods did not change their percentage ratio.

In the formed "strength - time" dependence, an increase in the motion power is observed, which is expressed by weightlifters in the experimental group during the barbell clean. This is one of the criteria of the sports skills improvement (Zhekov, 1976; Zhukov, 2006).

\section{Conclusions}

The presented materials contain results of the efficiency check of weightlifters' jerk training exercises using the machine with variable resistance modes. We suggested that performance of exercises on the machine with variable resistance modes would allow to reserve a high degree of combination with the main competitive exercise (the clean and jerk) on the one hand, and to influence selectively on the speed and strength capabilities of the group of muscles determining the successful results in this exercise, on the other hand.

Besides, application of the machine with the variable resistance modes will be one of the ways for overcoming the 
undesirable adaptation to the training loads and transfer of the whole body to a higher functioning level by means of the specific resistance modes developed by the machine, and of the high intensity of the performed exercises.

Upon pedagogical results summarizing, the advantage of this applied training means was discovered. It is represented by the improvement of some biomechanical and pedagogical indicators characterizing optimal performance of the competitive exercises.

First of all, it was expressed in the increase of the classic exercises results. The increment occurred not only in the clean and jerk, which was performed in a completely controlled environment, but also in the classic snatch. It can be explained by the increased speed and strength potential fulfilled in such a similar by structure exercise as the snatch and the clean.

The increased strength of weightlifters of the experimental group is indicated by the significant difference between the strength display in the start position and the barbell squats, which are the informative indicators of the weightlifters' physical fitness. The advantage achievement is explained by a larger load created by the variable resistances device on the muscles of the lower limbs and the back in the stretched position during exercises performance in the decreasing resistance mode.

The sports skills improvement should primarily consider application of the non-conventional training means-the use of machines, equipment, and techniques allowing better to disclose the functional reserves of the athlete's body, providing the interrelated improvement of various motor qualities improving the efficiency of the training sessions without a significant increase in the average loads values.

Performance of the jerk exercises on a machine with variable resistance modes, and, primarily, with the use of the variable modes providing load reduction with the barbell motion speed increase, fully complies with the requirements of the combined development method and adherence to the "dynamic conformance" principle.

The increased speed capabilities are the evidence of the cumulative effect from the use of the exercises performed in the decreasing resistance mode conditions, which also influenced the increased inter-muscular coordination level.

A larger load generated by the variable resistances device for the muscles of the lower limbs and the back in the stretched position during exercises performance in the decreasing resistance mode, contributed to a significant increment of strength display in the start position and barbell squats, which are the informative indicators of the weightlifters' physical fitness.

\section{References}

Avanesov, V.S. (1970). Biodinamicheskoe obosnovanie ratsional'nogo podbora uprazhnenii v trenirovke tiazheloatletov [Biodynamic justification of the rational selection of exercises for the weightlifters' training]. Extended abstract of the candidate's thesis, Moscow [in Russian].

Baechle, T.R., \& Earle, R.W. (2008). Essentials of strength training and conditioning. Beachle: Human Kinetics.

Bozhko, A.I., \& Baroga, A. (1979). Universal'nyi silovoi trenazher [Universal weight machine]. Tiazhelaia atletika: Ezhegodnik Weightlifting: Annual publication. Moscow: Fizkultura i sport [in Russian].

Cherkesov, lu.T. (1993). Problema i metodicheskie vozmozhnosti determinatsii rezhimov silovogo vozdeistviia sportsmenov s ob"ektami upravliaiushchei predmetnoi sredy [Problem of methodological opportunities of determination of the strength action modes of the sportsmen with the objects of the control subject environment]. Extended abstract of the candidate's thesis, Moscow [in Russian].

Cherkesov, Iu.T., Zhukov, V.I., Doronin, A.M., et al. (1991). Ustroistvo dlia trenirovki tiazheloatletov. Avtorskoe svidetel'stvo (A. S.) 1673142 SSSR [Device for weightlifters training. Author's certificate (A. c.) USSR]. Biulleten' izobretenii - Bulletin of inventions, 32 [in Russian].

D'iachkov, V.M. (1972). Kriterii tekhnicheskogo masterstva v sporte [Criteria of technical skills in sports]. Voprosy upravleniia protsessom sovershenstvovaniia tekhnicheskogo masterstva - Issues of the management of the technical skills improvement process. Moscow [in Russian].

Dobrovol'skii, I., Chicherin, A., \& Shchupletsov, S. (1977). Trenazhery dlia razvitiia skorostno-silovykh kachestv [Machines for development of the speed and strength qualities]. Legkaia atletika - Track and field athletics, 8, 20 [in Russian].

Donskoi, D.D. (1972). Upravlenie perestroikoi sistemy dvizhenii [Management of the motions system reorganization]. Teoriia i praktika fizicheskoi kul'tury - Theory and practice of the physical culture, 9, 13-15 [in Russian].

Doronin, A.M. (2006). Sovershenstvovanie biomekhanicheskoi struktury dvigatel'nykh deistvii sportsmenov na osnove reguliatsii rezhimov myshechnogo sokrashcheniia [Improvement of the biomechanical structure of the sportsmen's motor actions on the basis of the muscles contraction modes regulation]. (2 ${ }^{\text {nd }}$ ed.). Slavyansk-On-Kuban: Izdatel'skii tsentr SGPI [in Russian].

Drozdov, V.F. (1982). Metodika issledovaniia usilii, prilagaemykh tiazheloatletom k shtange i opore [Methodology of examination of the forces applied by a weightlifter to the barbell and support]. Tiazhelaia atletika: Ezhegodnik - Weightlifting: Annual publication. Moscow: Fizkultura i sport [in Russian].

Errera, K.A. (1981). Metodika sovershenstvovaniia tekhniki tolchka shtangi ot grudi v protsesse stanovleniia sportivnogo masterstva [Methodology of improvement of the barbell clean lifting techniques in the process of sports skills development]. Extended 
abstract of the Candidate's thesis, Moscow [in Russian].

Fick, A. (1864).Untersuchungen Uberelektrische Nervenzeizung.

Gisin, M.S., Lelikov, S.I., \& Stepanova, S.V. (1982). O vzaimosviazi sostava tela s ob"emom i intensivnost'iu trenirovochnykh nagruzok u tiazheloatletov vysokoi kvalifikatsii [Concerning interrelation of the body composition with the volume and intensity of the training loads among high-qualification weightlifters]. Tiazhelaia atletika: Ezhegodnik - Weightlifting: Annual publication. Moscow: Fizkultura i sport [in Russian].

Ivanov, V.V. (1976). Voprosy sovershenstvovaniia trenirovochnogo protsessa v sporte na osnove primeneniia spetsializirovannykh tekhnicheskikh sredstv obucheniia i kontrolia [Issues of the training process improvement in sports on the basis of application of the specialized technical means of training and control]. Extended abstract of the candidate's thesis, Moscow [in Russian].

Korenberg, V.B. (1979). Osnovy kachestvennogo biomekhanicheskogo analiza [Basics of the proper biomechanical analysis]. Moscow: Fizkultura i sport [in Russian].

Krasov, E.A. (1982). Struktura spetsial'no-vspomogatel'nykh uprazhnenii i pod"ema shtangi na grud' [Structure of the special auxiliary exercises and barbell clean lifting]. Extended abstract of the Candidate's thesis, Moscow [in Russian].

Levshunov, N.P. (1982). Tekhnika tolchka shtangi v zavisimosti ot morfologicheskikh osobennostei tiazheloatletov [Technique of the barbell push depending on the morphological peculiarities of the weightlifters]. Extended abstract of the Candidate's thesis, Malakhovka [in Russian].

Mamii, A.R. (2006). Proiavlenie skorostno-silovykh sposobnostei pri razlichnykh rezhimakh sokrashcheniia myshts nizhnikh konechnostei [Display of the speed and strength capabilities under various modes of contraction of the low extremities muscles]. Vestnik Adygeiskogo gosudarstvennogo universiteta - Bulleting of the Adygei State University, 1, $283-285$ [in Russian].

Medvedev, A.S. (1981). Osnovy sportivnoi tekhniki, planirovaniia i postroenie trenirovki tiazheloatletov vysshikh sportivnykh razriadov(metodicheskoe pis'mo) [Basic of the sports technique, planning and structurizing of training for the weightlifters with the highest sports categories (methodical letter)]. Moscow: GTsOLIFK [in Russian].

Ratov, I.P. (1972). Issledovaniia sportivnykh dvizhenii i vozmozhnostei upravleniia izmeneniiami ikh kharakteristik s ispol'zovaniem tekhnicheskikh sredstv [Examinations of the sports achievements and possibilities to control changes of their characteristics with the technical means application]. Extended abstract of the Candidate's thesis. Moscow [in Russian].

Samsonova, A.V. (2011). Gipertrofiia skeletnykh myshts cheloveka: monografiia [Hypertrophy of the human skeletal muscles: monograph]. ST Petersburg: National State University of the Physical Culture, Sports and Health named after P.F. Lesgaft [in Russian].

Skripko, A.D. (2003). Tekhnologii fizicheskogo vospitaniia [Technologies of the physical education]. Minsk: ISZ [in Russian].

Slobodian, A.P. (1973). Ekperimental'noe issledovanie effektivnosti sochetaniia razlichnykh rezhimov myshechnoi deiatel'nosti v trenirovke tiazheloatletov [Experimental research of the efficiency of combination of various modes of muscles activity in weightlifters training]. Extended abstract of the Candidate's thesis, Leningrad [in Russian].

Stone, M.H., Stone, M., \& Sands, W.A (2007). Principles and practice of resistance training. Human Kinetics.

Vaitsekhovskii, S.M. (1979). Operativnoe upravlenie protsessom sportivnoi trenirovki (na primere plavaniia) [Operative control over sports training process (through the example of swimming)]. Teoriia i praktika fizicheskoi kul'tury - Theory and Practice of the Physical Culture, 1, 47-50 [in Russian].

Verkhoshanskii, lu.V. (1988). Osnovy spetsial'noi fizicheskoi podgotovki sportsmenov [Basic concepts of the special physical training of the sportsmen]. Moscow: Fizkultura i sport [in Russian].

Vorob'ev, A.N. (1981). Tiazhelaia atletika: Uchebnik dlia in-tov fiz.kult' [Weightlifting - Handbook for the institutes of physical culture] (3rd ed. reviewed and supplemented). Mocow: Fizkultura i sport [in Russian].

Zatsiorsky, V.M., \& Kramer, W.J. (2006). Science and Practice of Strength. Human Kinetics.

Zhekov, I.P. (1976). Biomekhanika tiazheloatleticheskikh uprazhnenii [Biomechanics of the weight-lifting exercises]. Moscow: Fizkultura i sport [in Russian].

Zhukov, V.I (2006). O vozmozhnostiakh primeneniia trenazherov v trenirovke tiazheloatletov [Concerning possibilities of machines application for the weightlifters training]. Vestnik AGU - ASU Bulletin, 4, 317-326 [in Russian]. 